\section{Discussion}

The possibility that NF-I is linked to markers on chromosome $4 \mathrm{q}$ appears to have been excluded by the data in table 2 , a conclusion consistent with the findings of other investigators. In addition, the genes for TGFA, EGF, GRL, and EGFR, which may be considered 'candidate genes' for NF-I, show no evidence of close linkage. Eleven other loci selected on the basis of convenience also show no evidence of linkage.

\footnotetext{
References

' Dunn BC, Ferrell RE, Riccardi VM. A genetic linkage study in 15 families of individuals with Von Recklinghausen neurofibromatosis. Am J Med Genet 1985;22:403-7.

2 Huson SM, Meredith AL, Sarfarazi M, et al. Evidence against linkage of Von Recklinghausen neurofibromatosis and chromosome 19 markers. Ann NY Acad Sci 1986;486:349-53.

3 Riccardi VM, Carey JC. Von Recklinghausen neurofibromatosis and genetic linkage studies: clinical considerations. $J$ Med Genet 1987;24:521-2.

${ }^{4}$ Human Gene Mapping 8. Cytogenet Cell Genet 1985;40.

5 Ott $\mathrm{J}$. Estimation of the recombination fraction in human pedigrees: efficient computation of the likelihood for human linkage studies. Am J Hum Genet 1974;26:588-97.

${ }^{6}$ Lathrop GM, Lalouel JM. Julier C, Ott J. Multilocus linkage analysis in humans: detection of linkage and estimation of recombination. Am J Hum Genet 1985;37:482-98.

${ }^{7}$ Cox DW, Andrews BJ, Wills DE. Genetic polymorphism of alpha-2-HS-glycoprotein. Am J Hum Genet 1986;38:699-706.

${ }^{8}$ Kamboh MI, Ferrell RE. Genetic studies of human apolipoproteins. I. Polymorphism of apolipoprotein A-IV. Am J Hum Genet (in press).

9 Kamboh MI, Kirk RL, Clark P. Alpha-1-antitrypsin types in Asian, Pacific and Aboriginal Australian populations. Dis Markers 1983;1:33-42.

11) Whitehouse DB, Putt W. Immunological detection of the sixth
}

complement component following flat bed polyacrylamide geק isoelectric focusing and electrophoretic transfer to nitrocellu? lose filters. Ann Hum Genet 1983;47:1-8.

" Dykes DD, Mount M. Polesky HF. Parentage testing using the serum protein plasminogen. Am J Clin Pathol 1983;82:722-5.0

12 Escallon ME, Kamboh MI, Ferrell RE. Genetic studies of low abundance human plasma proteins. V. Improved typing of orosomucoid by isoelectric focusing and immunoblotting. Hum Hered (in press)

13 Dykes DD. Polesky HF. F-XIII-A phenotyping by isoelectric focusing and immunoblotting: gene frequencies in a populations of US whites and blacks. Electrophoresis 1985;6:521-3.

14 Kamboh MI. Ferrell RE. Genetic studies of low abundance human plasma proteins. III. Population genetics of coagulation factor 13B. Am J Hum Genet 1986;39:817-25.

15 Bock SC, Levitan DJ. Characterization of an unsual DNA length polymorphism $5^{\prime}$ to the human antithrombin III gene? Nucleic Acids Res 1983:11:8569-82.

${ }^{16}$ Murray JC, Beutow KH, Bell GI. RFLPs for transforming growth factor alpha (TGFA) gene at 2p13. Nucleic Acids Reico 1986;14:7136.

17 Murray JC, Buctow KH, Carlock L, et al. A multipoint map of 11 loci on human chromosome 4. Am J Hum Genet (in press)

${ }^{18}$ Hollenberg SM, Weinberger C, Ong ES, et al. Preliminary structure and expression of a functional human glucocorticoidreceptor cDNA. Nature 1985:318:635-41.

${ }^{19}$ Murray JC. Buctow KH, Donavan M. et al. Linkage discquilib rium of plasminogen polymorphisms and assignment of the gen क्षD to human chromosome 6q26-q27. Am J Hum Genet (in press). 3

20) Ullrich A, Coussens L, Hayflick JS, et al. Human epiderma growth factor receptor cDNA sequence and aberrant expression of the amplified gene in A431 epidermoid carcinoma cells $\overrightarrow{0}$ Nature 1984;309:418-25.

21 Bell GI, Karam JH, Rutter WJ. Polymorphic DNA reginn adjacent to the 5' end of the human insulin gene. Proc Natl A Sci USA 1981:78:8759-63.

22 Goode ME, Daiger SP. Restriction fragment length polymor isms detected by lambda H3. Genetics 1983;104:530.

Correspondence and requests for reprints to Dr V MP Riccardi, NF Program, Baylor College of Medicine, 1 Baylor Plaza, Houston, Texas 77030, USA.

\title{
Linkage analysis of British and Indian families with Von Recklinghausen neurofibromatosis
}

\section{G P MATHEW*, K THORPE*, D F EASTON*, C CARTER*,} C WALLIS $\dagger$, Z WONG $\ddagger$, A J JEFFREYS $\ddagger$, AND B A J PONDER*

From ${ }^{*}$ the Institute of Cancer Research, Haddow Laboratories, Clifton Avenue, Sutton, Surrey SM2 5PX; the MRC Research Unit for Inherited Skeletal Disorders, Department of Human Genetics, University of Cape Town Medical School, Observatory 7925, South Africa; and $¥$ the Department of Genetics, University of Leicester, Leicester LE1 7RH.

SUMMARY Linkage analysis has been undertaken in two British and three South African Indian families with Von Recklinghausen neurofibrornatosis. Eleven polymorphic DNA

Received for publication 20 March 1987 Accepted for publication 24 March 1987. probes were studied, including both random ${ }_{0}^{\omega}$ DNA sequences and candidate oncogenes Although no evidence for linkage of these probes to the disease was detected, substantial exclusion regions were established on six of the chromosomes studied. 
Von Recklinghausen neurofibromatosis (VRNF) is a relatively common autosomal dominant disorder characterised by café au lait spots, cutaneous neurofibromas, and an increased risk of central nervous system tumours. ${ }^{1-3}$ The pathogenesis of the disorder is unknown and no laboratory diagnostic test is available. Several genetic linkage studies have been undertaken in order to map the locus of the VRNF gene, ${ }^{4-8}$ but none of these has detected a significant linkage between a marker and the disorder. We have therefore tested a further 11 polymorphic DNA markers as part of the international effort to locate the affected gene.

\section{Materials and methods}

Families were ascertained through the British Neurofibromatosis Patients' Association, LINK, and the records of the Department of Human Genetics, University of Cape Town Medical School. The criteria for the diagnosis of VRNF were as follows. (1) In adults, six or more café au lait spots $>1.5 \mathrm{~cm}$ in diameter and multiple cutaneous neurofibromas. (2) In children, an affected parent and six or more café au lait spots $>1.5 \mathrm{~cm}$ in diameter.

All subjects included in the linkage analysis were more than five years old. Blood specimens were obtained from two British families and three South African families of Indian descent. A total of 73 subjects was sampled, which included 37 affected subjects and 62 potentially informative meioses. DNA isolation, blotting, and hybridisation were performed as described previously. ${ }^{9}$ The probes used were as follows: seven locus specific minisatellite sequences ${ }^{910}$ (unpublished data), the hypervariable region $3^{\prime}$ to the $\alpha$ globin genes, ${ }^{11}$ the erb A $2^{12}$ and sis ${ }^{13}$ oncogenes, and $22 \mathrm{cl}-18,{ }^{14}$ which is a random sequence on chromosome 22 .

Likelihood computations were carried out using a modification of the LINKAGE programme. ${ }^{15}$ The VRNF gene was assumed to have a population frequency of $2 \times 10^{-4}$ and a penetrance of $100 \%$. Rapid computation of lod scores for the minisatellite sequences, which have multiple alleles, was facilitated by recoding the genotypes of some subjects so that at most four alleles were used. ${ }^{16}$

\section{Results and discussion}

The lod scores at recombination fractions from 0 to 0.4 are shown in the table. No evidence for linkage of any of the probes tested to the VRNF gene was obtained. However, use of the highly polymorphic minisatellite probes ${ }^{1011}$ has established large regions of exclusion on chromosomes $1,5,6,7,11$, and 12. Assuming that the exclusions do not overlap and that none of the probes is located near the end of a chromosome, a total of $236 \mathrm{cM}$ (approximately $8 \%$ of the human genome) has been excluded for VRNF at a lod score of -2 or less. The data also appear to exclude the sis and erb A2 oncogenes as candidate genes for VRNF. Future work will concentrate on the use of probes with high frequency restriction fragment length polymorphisms from regions of the genome where large exclusions for the VRNF gene have not been reported. The exclusion map published in this issue ${ }^{17}$ will facilitate the search.

We would like to thank Margaret Ponder for assistance in obtaining the family material, D Higgs for the hybridisations with the $\alpha$ globin gene HVR probe, and $\mathrm{M}$ Ormerod for advice on a linkage computer programme. We also thank P Middleton, A Hall, and C Buys for the erb A2, sis, and 22cl-18 probes. This work was supported by grants from the Cancer Research Campaign, the Medical Research Council, and 'LINK', the neurofibromatosis associa-

TABLE Lod scores for linkage between VRNF and 11 polymorphic DNA probes.

\begin{tabular}{|c|c|c|c|c|c|c|c|c|c|c|c|c|}
\hline \multirow[t]{2}{*}{ Gene } & \multirow[t]{2}{*}{ Probe } & \multirow[t]{2}{*}{ Chrom $^{+}$} & \multicolumn{7}{|c|}{$Z$ at recombination fraction } & \multicolumn{2}{|c|}{$Z \max$} & \multirow{2}{*}{$\begin{array}{l}\text { Exclusion } \\
\theta \text { at } \\
Z=-2\end{array}$} \\
\hline & & & 0 & $0 \cdot(0) I$ & 0.05 & $0 \cdot 1$ & $0 \cdot 2$ & $0 \cdot 3$ & 0.4 & $Z$ & $\theta$ & \\
\hline DiS8 & $\lambda \mathrm{MS} 32$ & $1 \mathrm{q}$ & $-x$ & -13.79 & $-3 \cdot 79$ & $-2 \cdot 20$ & -0.85 & -0.31 & $-0 \cdot 12$ & $0 \cdot(\mathbf{0})$ & 0.50 & $0 \cdot 10$ \\
\hline D5S43 & $\lambda \mathrm{MS} 8$ & 5 & $-x$ & $-32 \cdot 19$ & $-8 \cdot 89$ & $-5 \cdot 20$ & $-2 \cdot 09$ & $-0 \cdot 81$ & $-0 \cdot 25$ & $0 \cdot(0)$ & 0.50 & $0 \cdot 20$ \\
\hline D6* & $\lambda \mathrm{MS} 29$ & 6 & $-x$ & $-28 \cdot 78$ & $-8 \cdot 65$ & $-5 \cdot 32$ & $-2 \cdot 33$ & -0.91 & -0.21 & $0 \cdot 00$ & $0 \cdot 50$ & $0 \cdot 21$ \\
\hline D7S21 & $\lambda \mathrm{MS} 31$ & $7 \mathrm{pter} \rightarrow \mathrm{q} 22$ & $-x$ & $-28 \cdot 18$ & $-8 \cdot 12$ & $-4 \cdot 86$ & $-2 \cdot(01$ & -0.73 & $-0 \cdot 16$ & $0 \cdot(x)$ & 0.50 & 0.20 \\
\hline D12S11 & $\lambda \mathrm{MS} 43$ & 12 & $-x$ & $-28 \cdot 18$ & $-8 \cdot 12$ & $-4 \cdot 86$ & $-2 \cdot 01$ & -0.74 & $-0 \cdot 16$ & 0.100 & 0.50 & $0 \cdot 20$ \\
\hline HBA & pa3'HVR.64 & $16 \mathrm{p} 13$ & $-x$ & $-4 \cdot 20$ & -0.91 & -0.42 & -0.07 & 0.02 & 0.01 & 0.02 & 0.33 & 0.01 \\
\hline ERBA2 & pHEA2 & $17 q 11$ & $-x$ & $-4 \cdot 11$ & -0.85 & -0.38 & -0.166 & $0 \cdot 01$ & $0 \cdot(0)$ & 0.01 & $0 \cdot 31$ & 0.01 \\
\hline SIS & V-SIS & $22 q 12 \rightarrow 13$ & $-x$ & $-2 \cdot 40$ & -0.72 & $-0 \cdot 44$ & $-0 \cdot 19$ & -0.08 & $-0 \cdot 02$ & $0 \cdot(x)$ & 0.50 & $0.0 \times 12$ \\
\hline D22S10 & $22 \mathrm{cl}-18$ & 22 & $-x$ & $-2 \cdot 10$ & -0.46 & -0.23 & $-0 \cdot(16$ & -0.02 & 0.00 & $0 \cdot 00$ & 0.50 & 0.001 \\
\hline
\end{tabular}

${ }^{*}$ These minisatellite probes have not yet been assigned HGM symbols. The regional assignments of $\lambda$ MS1 and $\lambda$ MS32 are provisional. ${ }^{y}$

†Chrom $=$ chromosomal localisation. 
tion. AJJ is a Lister Institute Research Fellow. The minisatellite probes are the subject of Patent Applications and commercial enquiries should be addressed to the Lister Institute of Preventive Medicine, Brockley Hill, Stanmore, Middlesex HA7 4JD, UK.

\footnotetext{
References

1 Riccardi VM. Von Recklinghausen neurofibromatosis. $N$ Engl J Med 1981;305:1617-27.

2 Sorensen SA, Mulvihill JJ, Nielsen A. Long-term follow-up of Von Recklinghausen neurofibromatosis. N Engl J Med 1986; 314:1010-5.

3 Riccardi VM, Carey JC. Von Recklinghausen neurofibromatosis and genetic linkage studies: clinical considerations. $J$ Med Genet 1987;24:521-2.

${ }^{4}$ Spence MA, Bader JL, Parry DM, et al. Linkage analysis of neurofibromatosis (Von Recklinghausen disease). J Med Genet 1983;20:334-7.

5 Dunn B, Ferrell RE, Riccardi VM. A genetic linkage study in 15 families of individuals with Von Recklinghausen neurofibromatosis. Am J Med Genet 1985;22:403-7.

6 Darby JK, Feder J, Selby M, et al. A discordant sibship analysis between $\beta$-NGF and neurofibromatosis. Am J Hum Genet 1985;37:52-9.

7 Huson SM, Meredith AL, Sarfarazi M, Shaw DJ, Compston DAS, Harper PS. Linkage analysis of peripheral neurofibromatosis (Von Recklinghausen disease) and chromosome 19 markers linked to myotonic dystrophy. J Med Genet 1986;23:55-7.

* Dietz JN, Robbins T, Cannon LA, et al. Linkage analysis of Von Recklinghausen neurofibromatosis: chromosomes 4 and 19. Genet Epidemiol 1986;3:313-21.
}

${ }^{y}$ Wong Z, Wilson V, Patel I, Povey S, Jeffreys AJ. Characterisation of a panel of highly variable minisatellites cloned from human DNA. Ann Hum Genet (in press).

10 Wong Z, Wilson W, Jeffreys AJ, Thein SL. Cloning a selected $\overline{\overline{\bar{S}}}$ fragment from a human DNA 'fingerprint': isolation of an extremely polymorphic minisatellite. Nucleic Acids Res 1986; 14:4605-15.

"Higgs DR, Wainscoat JS, Flint J, et al. Analysis of the human $\alpha$ क globin gene cluster reveals a highly informative genetic locus. Proc Natl Acad Sci USA 1986;83:5165-9.

12 Middleton PG, Angelis CD, Weir-Thompson EM, Steel CM. ొొ RFLP for the human erb A2 gene. Nucleic Acids Res 1986;14:1925.

13 Julier C. Lathrop M. Lalouel JM, Reghis A, Szajnert MF Kaplan JC. New restriction fragment length polymorphisms onc human chromosome 22 at loci sis, $M B$ and IGLV. Cytogenes Cell Genet 1985;40:664.

14 Hofker MH, Breuning MH, Bakker E, Van Ommen GJB Pearson PL. An anonymous single copy chromosome 22 clone, D22S10 (22cl-18), identifies an RFLP with PstI. Nucleic Acids Res 1985:13:7167.

15 Lathrop GM, Lalouel JM, Julier C, Ott J. Multilocus linkageN analysis in humans: detection of linkage and estimation of recombination. Am J Hum Genet 1985;37:482-98.

$16 \mathrm{Ott} \mathrm{J}$. Method for recoding alleles to improve calculationefficiency. Am J Hum Genet 1974;26:588-97.

17 Sarfarazi M. Huson SM, Edwards J. An exclusion map for Von $\mathbb{\oplus}$ Recklinghausen neurofibromatosis. J Med Genet 1987;24: $\frac{\overrightarrow{\mathbb{D}}}{3}$ 515-20.

Correspondence and requests for reprints to DrD C G P Mathew, Institute of Cancer Research $\overrightarrow{0}$ Haddow Laboratories, Clifton Avenue, Suttog Surrey SM2 5PX.

\section{Linkage analysis of neurofibromatosis}

\section{S KITTUR*, M L LUBS $\dagger$, M BAUER $\dagger$, A CHAKRAVARTI H KAZAZIAN*}

From * the Department of Pediatrics, Johns Hopkins Institution, Baltimore, Maryland; the Department of Genetics, University of Miami, Florida; and $\ddagger$ the Department of Biostatistics, University of Pittsburgh, Pittsburgh, Pennsylvania, USA.

SUMMARY Linkage analysis of neurofibromatosis was performed using genes on chromosomes $1,8,11$, and 12 . No linkage was found between NF and C-myc, AT 3, IGF-1, PTH, and gamma globin genes. Evidence for linkage was found between C-ets 1 , on the long arm of chromosome 11 and NF in two families with a lod score of 1.88 at $\theta=0$. More families are being studied to confirm this linkage.

Neurofibromatosis (NF) is one of the common autosomal dominant neurological disorders with a frequency of approximately 1 in 3000 . The disease is

Received for publication 23 March 1987 Accepted for publication 24 March 1987. mainly characterised by café au lait spots andं neurofibromas. These patients have an unusually? high frequency of malignancy compared to theo normal population. The intriguing question is, what gene do they carry that predisposes them tog malignancy? In order to localise the gene for NF, $>$ linkage analysis using DNA markers was performed.

Three multi-generation families shown in table 1 N were used.

Oncogene C-myc, insulin like growth factor-1 $N$ antithrombin-3, parathyroid hormone, and gammo globin genes ${ }^{1-5}$ were not linked to neurofibromatosiso in our families. The lod scores are shown in table 26

We found a positive lod score of 1.88 with oncogene C-ets $1^{6}$ in two informative families (no recombinants observed in six informative meioses).0 These data provide suggestive evidence that the NFO 